\title{
Attitudes and Behavior of Vietnamese toward to Consumer Affinity in Term of Travel Abroad
}

\author{
Ma Bich Tien \\ Faculty of Commerce and Business Administration \\ Van Lang University, HCMC, Vietnam \\ E-mail: mabichtien@vanlanguni.edu.vn
}

Received: April 17, 2018 Accepted: April 29, 2018 Published: May 23, 2018

doi:10.5296/ber.v8i2.13009ＵRL: https://doi.org/10.5296/ber.v8i2.13009

\begin{abstract}
s
With the significant growth of business globalization has brought major change to consumption patterns. This leads the operation and marketing activities of business must be change to adapt this challenges, specifically international marketing. Consumer affinity is one of these important approaches. Consumer affinity refer emotional connections forged between consumers and a particular brand or business. In recently, Vietnamese prefer to travel abroad than domestic. Hence, this study will explore the attitude and behavior of the local people in the tourism -toward travel in other countries should done first, this study is done for that objective. To gain the findings which are as guideline for tourism marketing travel discipline, the deductive and qualitative research approaches are adapted, which is data come from two sources of primary and secondary data. The results showed that consumer affinity impacts the attitudes and behavior of local people toward on willingness to buy and the willingness to travel more for foreign countries. The study is expected to contribute not only to practice but also theory or consumer affinity with the further researches.
\end{abstract}

Keywords: Attitudes, Behavior, Consumer affinity, Tourism (travel), Vietnam

\section{Introduction}

In recently days, companies and brands must face with many challenges because of the widespread of communication and globalization. Customers have more awareness and selection opinions. Moreover, the large number of potential consumers and economy growth and rapid raise of people's expectations and consumption had led made developing countries a good target spectators for developed these. Besides, although low salary, but with high population and increase consumption for consumer goods and services in developed countries (Meyer \& Tran, 2006), and in general it has made them an attractive target for the developed. 
Therefore, foreign companies are trying to attract this target.

A some of research have studied Vietnamese consumer behavior toward oversea brands and the focus of studies was influences of cultural orientation. Nguyen et al. (2008) have found that consumer positively influenced imported product judgement such as the level of awareness, understanding and acceptance of the values of other culture. Moreover, Nguyen and Smith (2012) identified Vietnamese consumers have negative impact of ethnocentrism and the positive influence of modern status orientation such placing a high value on luxury objects, being rich, and being talented enough to earn a high income, thus they willingness to buy imported products and travel oversea countries.

Vietnam is one of the most attractive markets in the world with their substantial economic growth and increasing number of middle class. The economy grew $6.81 \%$ with $8 \%$ construction, 7,44\% service increase and 10.9\% of retail sales gain in 2017 (Phuong, 2017). In addition, Vietnam is an attracting market for foreign marketers with over 90 million people and an average annual growth rate of 10-15\% (Tran, 2015). Besides, it is forecasted that the middle class will be tripled in Vietnam between 2012 and 2020 ("Vietnamese Consumers", 2013). With significant growth in middle class, Vietnamese consumers are buying more sophisticated products and services. For example, urban Vietnamese women aged between 20 and 45 have increased their spending on apparel up to $18 \%$ of their monthly income (Breu et al., 2010). Vietnamese consumers show great interests in foreign products as well as travel in foreign countries as their demands get more cultivated (PricewaterhouseCoopers LLP. 2005).

In Vietnam context, in the year of 2016, about 6.5 million of Vietnamese made the outbound tours, 15\% increase with the last year 2015 (Quyen, 2017). In recently years, Vietnamese are more interested in travel in others countries. In the average, each Vietnamese visitor travel 5 times in the last 2 years. In particular, Thailand, Korea, Japan and Singapore are the most select destinations (Quyen, 2017)

Consumer affinity means is "a sense of love, sympathy or even continuity and affiliation to a particular country and considering it their own (Oberecker et al, 2008), we can expect when this sense is created inside a consumer towards a country, the consumers tend to buy more products or even is willing to pay more for the products of that particular country

Therefore, this study is to seek and present the finding the behavior and attitude of local people tend to consumer affinity on the willingness to buy and the willingness to travel in oversea countries discipline in Ho Chi Minh.

\section{Literature Review}

\subsection{Concept of Consumer Affinity}

The theoretical of consumer affinity is mostly based on social identity theory (Tajfel, 1982). This theory distinguishes between in-groups and out-groups. In Social Identity Theory, a person has not only one "personal self," but also several social selves. Besides, this theory shows that people classified themselves to different classes. The classification can be based on age, gender, occupation, country of origin by being in this category. In-groups are those 
that considered a part of their group and out-groups are those that considered not a part of their group (Lawrence, 2012). Oberecker et al (2008) have stated that in groups are preferred over out groups. Thus, people who have develop affinity which toward a foreign country because they identify themselves in this country, and they assume it is their own country (Bertin Nes et al.2014).

According to Joff and Neben Zohal (2006), defined consumer affinity but their model was not test experimentally. Oberecker and Diamantopoulos (2011) was have a single cue study in their measure of willingness to buy, and such studies have generally higher effects than multi-cue studies (Verlegh \& Steenkamp, 1999). In study of Oberecker and Diamantopoulos (2011), The impact of consumer affinity on willingness to buy in needs to be confirmed in a multi-cue setting or by actual product ownership.

As a founding from consumer affinity of Bertin Nes at al. (2014), the components of affinity can be divided to four drivers including one macro and three micro drivers.In their research, they have concluded that consumer affinity components are as follows:

- Culture: Oberecker et al (2008) identified value and traditions can strengthen the sense of affinity and "sense of cultural proximity" can influence to beliefs about other countries (Bretin Nes et al., 2014)

- Art and history: many of items related to art, architecture, and history of the country can influence affinity (Bretin Nes et al., 2014)

- People: as found of Oberecker et al (2008) affinity towards the people of a country can translate into affinity towards the country itself. Hardworking people, great people, fondness for the people, customer service, work ethic, easy going, laid back, strong values, resourceful, productive, sense of humor, friendly, polite, welcoming, outgoing, diverse people, enjoy life, happy, educated, creative, and sincerity were mentioned as attributes that influenced affinity towards the country (Bretin Nes et al., 2014)

- Weather condition: Verlegh (2001) viewpoint climate and atmosphere condition may have a positive influence on attitudes on particular country (Bretin Nes et al., 2014)

- Food: food is a key of visible feature of each country. When people interest in foods or drink of particular country, they will memory that country. It creates a sense of affinity.

- Family and friends: The United States is a country of immigrants. Many U.S citizen argue that the have a special feeling to the country of origin. Moreover, keeping contact with family and friends who live in the country and had positive experiences was a source of affinity. (Bertin Nes et al., 2014).

- Travel: Travel is connected to the personal experience in a specific country that depend on how long a trip such as long term or short term experience. The experience can be increasing affinity feelings towards a particular country. In addition, Travel and family and friends can be considered an emotional aspects and other dimensions can be considered large dimensions that are relevant to the countries (Bertin Nes et al., 2014). 


\subsection{Overview of Customer Attitudes and Behavior}

In marketing discipline, the term "customer (customers)" and consumer almost are used interchangeably. However, the customer and the consumer is not strictly speaking the same. A customer is a person or company who purchases goods and services. A customer becomes a consumer when he or she uses the goods or services i.e. where there is some consumption. Also, there are many classifications of customers like internal - external customers, potential customer, loyal customers, discount customers, impulse customers, need-based customers, wandering customers, etc. In the aspects of attitude of customers is really important and at present, attitude occupies a central role in the theories and research regarding consumer behavior (Ajzen, 2008). In case, if an individual shows the positive attitude towards a product/service, it is more likely to make a purchase. Thus, the study of consumer attitudes is crucial for a marketer and marketing discipline. Blackwell et al. (2001) define attitudes represent what one likes and dislikes or the positive and negative feelings has towards an object.

As viewpoints of Hawkins et al. (2004), attitude is seen as "an enduring organization of motivational, emotional, perceptual and cognitive processes with respect to some aspect of our environment. However, attitude is defined as an "overall evaluation that expresses how much we like or dislike an object, issue, person or action" (Petty et al., 1991; Hoyer \& Macinnis, 2001; Solomon, 2004). Additionally, an attitude is an enduring combination of cognitive, emotional, and behavioral processes (Neal et al., 2004) or mental states by which consumers structure the way they perceive and respond to market environmental elements (Aaker et al., 1998) and the behavioral component of an attitude is "the tendency of the attitude holder to respond in a certain manner toward an object or activity" (Neal et al., 2004). Consumer attitudes comprise of a consumer's (1) beliefs about, (2) feelings about, (3) and behavioral intentions toward some object-within the context of marketing. These components are viewed together since they are highly interdependent and together represent forces that influence how the consumer will react to the object. However, in the study of Hawkins et al. (2004), three main components create the attitude of cognitive component (concerning the consumer's beliefs about a product, which can be generally evaluated); affective component (relating to the feelings or emotional reactions to an object) and behavior component.

\subsection{Overview of Consumer Affinity on Travel}

Tourism is one of vital factors to economy growth in the world. Consumer spending in Asia continues to grow steadily with rising incomes and increasing middle-class populations, giving tourism many opportunities. In recently days, middle - class tend to enjoy their life, they spend more money for travel and entertainment. In 2017, the tourism of Asia Pacific increased to $6.1 \%$, with $\$ 2.3$ trillion and 159 million visitors, while the strongest growth was experienced in Southeast Asia (8.3\%), which has benefited with rapid growth in the China outbound market, and South Asia (7.9\%), with Sri Lanka (10.7\%), Thailand (10.7\%), Vietnam (10.7\%), Philippines (8.9\%), Singapore (8.7\%), India (8.5\%), and Indonesia (5.8\%) contributing impressively (world travel $\&$ tourism council, 2017)

On the other hand, Vietnamese now tend to prefer outbound tours instead of domestic 
because of cheap and many promoting tours. Besides, Vietnamese traveler can easily travel in Southeast Asia region, with short - haul fight, cheap tickets and exempt visa. The destinations selected by most Vietnamese are Thailand, Korea, Japan and Singapore with an average of 4 nights or less (Quyen, 2017). Moreover, all these countries had representative offices in Vietnam to with an aim to attract more Vietnamese travelers to there. In 2016, there was 6.9 million Vietnamese tourists traveling abroad. It is expected to 7, 5 million in 2021.

\section{Methodology}

Aiming to seek and present the findings on the attitudes and behavior of the local people on consumer affinity on travel abroad discipline, the deductive and quantitative research approaches are adopted, where data come from the 2 sources of primary and secondary data. The deductive approach is the first method and it is seen as secondary data for the study. Secondary data is used as the foundation for primary data of which are from various databases including Google Scholar, Scopus, Science Direct for journals, books, and other relevant publications on the subject. Later, to reduce bias; the author uses the systematic and content analysis. Following of the secondary data is the primary data which is in term of survey by the questionnaire. A self-administered questionnaire has been developed, and then pretested to enhance its overall design. Pretest results revealed minor instances of ambiguous wording. In the questionnaire, there are 2 kinds of questions: open and close ones. Besides, the Likert style measurement is also used as from 1 to 5 as follows $5=$ strong agree, $4=$ agree, $3=$ neutral, $2=$ disagree and $1=$ strong disagree. To ensure a common aim, the opening section of the questionnaire contained a definition and brief explanation of consumer affinity. A total of 289 questionnaires have been distributed to people who are residing in Ho Chi Minh City with the age of 18 or above, of which 250 were returned and deemed valid for data analysis, representing a response rate of 86.85 per cent.

\subsection{Data Analysis}

There are 113 men (equivalence of 53\%) and 118 women (47\%) joining in the survey of which allocates $17.93 \%$ of them in age of $18-24,29.88 \%$ from $24-40,37.05 \%$ from $40-50$, $12.75 \%$ from $50-60$ and after 60 is at $2.39 \%$. In aspect of their professions, there are $13.15 \%$ as students, $63.35 \%$ as white-collared workers and $23.51 \%$ as blue - collared workers.

A total of $85 \%$ of the participants indicated that they were preferred travel aboard, they tend to affinity other countries (91\% participants respond "I like Japan/ Korea and 95\% respondents that "I feed fondness for Japan/Korea"). Furthermore, 81\% participants were travel to one destination in Asia in the last two years. The result gains a little difference among age and profession groups. The age group 22 to 40, students and the white collared workers are travelled by themselves while the age from 50 - 60 and after 60 who liked to travel by tour operators. Furthermore, $92 \%$ participants who are affinity to buy tour and travel in foreigner countries. $58 \%$ of them have an affinity for culture/ landscape, $23 \%$ for people, $18 \%$ for music/entertainment and $21 \%$ for politics. Regarding to the attitude exploration toward consumer affinity on willing to buy and travel abroad, the result is as follows: 


\section{Macrothink}

$5=$ strong agree, 4 = agree, $3=$ neutral, $2=$ disagree, $1=$ strong disagree

\begin{tabular}{|l|l|l|l|l|l|}
\hline & 1 & 2 & 3 & 4 & 5 \\
\hline $\begin{array}{l}\text { I spend money to travel in Japan/Korea because I } \\
\text { appreciate these country's history/art }\end{array}$ & $8 \%$ & $10 \%$ & $18 \%$ & $18 \%$ & $46 \%$ \\
\hline $\begin{array}{l}\text { I spend money to travel Japan/Korea because I appreciate } \\
\text { these foods and cuisines }\end{array}$ & $6 \%$ & $10 \%$ & $12 \%$ & $32 \%$ & $40 \%$ \\
\hline $\begin{array}{l}\text { I spend money to travel Japan/Korea because I like } \\
\text { the nature and landscape in there }\end{array}$ & $5 \%$ & $5 \%$ & $16 \%$ & $60 \%$ & $24 \%$ \\
\hline $\begin{array}{l}\text { I spend money to travel Japan/Korea because I like } \\
\text { the movie and entertainment from there }\end{array}$ & $20 \%$ & $30 \%$ & $20 \%$ & $30 \%$ & $20 \%$ \\
\hline $\begin{array}{l}\text { I spend money to travel Japan/Korea because these are } \\
\text { open friendly to foreigners }\end{array}$ & $10 \%$ & $14 \%$ & $60 \%$ & $10 \%$ & $6 \%$ \\
\hline $\begin{array}{l}\text { I spend money to travel Japan/Korea because I trust } \\
\text { the people living in these country }\end{array}$ & $20 \%$ & $20 \%$ & $10 \%$ & $40 \%$ & $10 \%$ \\
\hline $\begin{array}{l}\text { I spend money to travel Japan/Korea because I like } \\
\text { these government policies }\end{array}$ & $6 \%$ & $10 \%$ & $60 \%$ & $20 \%$ & $4 \%$ \\
\hline
\end{tabular}

Source: own

The table shows that Vietnamese have positive affinity feelings with Japan/ Korea. They willing to buy goods and travel in Japan/Korea. In particular, the landscape and foods contributed to significant on consumer affinity for travel abroad (with $84 \%$ for landscape and $72 \%$ for foods), the agreement will be high. Also, concerning to feelings and happies toward share information to family and friends about their travel abroad trips, the results are follows:

$5=$ strong agree, $4=$ agree, $3=$ neutral, $2=$ disagree, $1=$ strong disagree

\begin{tabular}{|l|l|l|l|l|l|}
\hline & 1 & 2 & 3 & 4 & 5 \\
\hline $\begin{array}{l}\text { Willing to share information with friends or others } \\
\text { about how to plan trip to Japan/Korea }\end{array}$ & $8 \%$ & $14 \%$ & $14 \%$ & $28 \%$ & $36 \%$ \\
\hline $\begin{array}{l}\text { Willing to share information with friends or } \\
\text { others about product/service knowledge about Japan/Korea }\end{array}$ & $12 \%$ & $6 \%$ & $25 \%$ & $27 \%$ & $30 \%$ \\
\hline Willing to pay for Japan/Korea goods in Vietnam & $12 \%$ & $20 \%$ & $30 \%$ & $22 \%$ & $16 \%$ \\
\hline $\begin{array}{l}\text { Willing to book air ticket, hotel to travel abroad if } \\
\text { they have a next vacation }\end{array}$ & $10 \%$ & $12 \%$ & $16 \%$ & $36 \%$ & $26 \%$ \\
\hline
\end{tabular}

Source: own

The table shows that in case of being willing to share information and trip experience with friends and others after travelling abroad. This rate is at $64 \%$. Therefore, with this case, consumer affinity has direct and positive relationship on willing to buying intentions. Furthermore, the respondents (about 62\%) also express that they willing to book air ticket, hotel to travel abroad if they have a next vacation. 


\section{Discussion and Conclusion}

The finding from data analysis section provide meaningful results to address the main research objective which are to identify the attitude and behavior of Vietnamese toward to consumer affinity in term of travel abroad. With "travel" products are difficult to evaluate before purchasing, consumer affinity is a key role in corporate identity and follow to business.

Firstly, this study finds that consumer affinity has a positive impact on consumer's the willingness to purchase foreign products and services. This result is consistent with the Bernard and Zarrouk-Karoui (2014), Oberecker and Diamantopoulos (2011) and Verlagh's (2007) results. Secondly, this study identified consumer affinity has a significant and positive impact on the consumer's the willingness to pay for foreign products and services. It is suitable with the results the Bernard and Zarrouk-Karoui's (2014) results. Besides, this research also determined consumer affinity has a significant and positive impact on the consumer's the willingness to share information to their relatives. Therefore, if consumers have a sense of affinity toward a country, they will feel belong this country. They are more willing to buy and pay for goods and services from that particular country.

With the population of Viet Nam is more 90 million, rising incomes and increasing middle-class populations. This creates the great chance for travel sectors. The character of tourism is invisible, consumer hard to evaluate products before purchasing, consumer product knowledge has a vital role in willingness to purchase and pay products or services. Further research should examine whether consumer knowledge has affects to the relationship between affinity and the willingness to purchase and pay more.

Affinity can provide the energy and motive for trust and other cooperative behaviors (Schmid, 2000). Trust and communication are important values in organizational buying and in international organizational relations (Nes, Solberg, \& Silkoset, 2007). Affinity related to the people, culture and nature, politics, and music and entertainment may stimulate better communication to customers. Besides, communication is vital role in the advertising of brands. Author concludes future research may find the efficiency of communications channel affect to the level of consumer affinity toward to other country. Furthermore, as known, each study will gain the limitation, this study is not exceptional. The study has its limitation in the scope because the survey is conducted only in travel industry and the sample collection in the convenience method. The distinction of age and profession groups is not also analyzed. Therefore, it is not a representative for others industry. Further research can be done to cover the limitations.

\section{References}

Aaker, J. L. (1998). Dimensions of brand personality. Journal of Marketing Research, 34(3), 347-356. https://doi.org/10.2307/3151897

Bernard, Yohan \& Zarrouk-Karoui, Sarra (2014). Reinforcing The willingness to purchase and to Pay Due to Consumer Affinity towards a Foreign Country. International Management Review, 10(2). 


\section{Macrothink}

Business and Economic Research ISSN 2162-4860 2018, Vol. 8, No. 2

Bertin Nes, Erik, Yelkur, Rama \& Silkoset, Ragnhild (2014). Consumer affinity for foreign countries: Construct development, buying behavior consequences and animosity contrasts. International Business Review, 23, 774-784. https://doi.org/10.1016/j.ibusrev.2013.11.009

Blackwell, R., Miniard, P., \& Engel, J. (2006). Consumer behavior. Consumer behavior: Building Market Strategy $9^{\text {th }}$ Ed. McGraw-Hill/Irwin.

Breu, M., Salsberg, B. S., \& Tú, H. T., (2010). Growing up fast: Vietnam discovers the consumer society. Forbes (23 August 2010). Retrieved from http://www.forbes. com/2010/08/23/vietnam-retailing-consumerism-leadership-managing-mckinsey. html.

Halle', n, L., \& Johanson, J. (1985). Industrial marketing strategies and different national environments. Journal of Business Research, 13(6), 495-509.

https://doi.org/10.1016/0148-2963(85)90044-X

Hawkins, Del I., Best, R. J., \& Coney, K. A. (2004). Consumer behavior: implications for marketing strategy (4th ed), New South Wales: McGraw-Hill.

Hofstede, G. (1980). Cultures consequences; International differences in work-related values. Beverly Hills, CA-London: Sage.

Jaffe, E. D., \& Nebenzahl, I. D. (2006). It's all in the eyes of the consumer. In National image $\&$ competitive advantage: The theory and practice of place branding. Copenhagen: Narayana Press.

Katz, D. (1960). The functional approach to the study of attitudes. Public opinion Quarterly, 24(2), 163-204. https://doi.org/10.1086/266945

Kressmann, F., Sirgy, M. J., Herrmann, A., Huber, F., Huber, S., \& Lee, D. J. (2006). Direct and indirect effects of self-image congruence on brand loyalty? Journal of Business Research, 59(9), 955-964. https://doi.org/10.1016/j.jbusres.2006.06.001

Lawrence, Steven, J (2012). Consumer Xenocentrism and Consumer Cosmopolitanism: The Development and Validation of Scales of Constructs Influencing Attitudes towards Foreign Product Consumption. Dissertation Submitted to the Graduate School of Wayne State University, Detroit, Michigan in partial fulfillment of the requirements for the degree of DOCTOR OF PHILOSOPHY.

Meyer, Klaus, E., \& Yen Thi Thu Tran (2006). Market Penetration and Acquisition Strategies for Emerging Economies. Long Range Planning, 39, 177-197.

https://doi.org/10.1016/j.lrp.2006.04.004

Neal, C., Quester, P., \& Hawkins, D. (2004). Consumer behavior: implications for marketing strategy (4th ed), New South Wales: McGraw-Hill.

Nguyen, T., \& Smith, K. (2012). The impact of status orientations on purchase preference for foreign products in Vietnam, and implications for policy and society. J. Macromarketing, 32(1), 52-60. https://doi.org/10.1177/0276146711421786 


\section{MInstitute Macrothink $_{\text {Intion }}$}

Business and Economic Research ISSN 2162-4860

Nguyen, T. D., Nguyen, T. M., \& Barrett, N. J. (2008). Consumer ethnocentrism, cultural sensitivity, and intention to purchase local products-evidence from Vietnam. Journal of Consumer Behavior, 7, 88-100. https://doi.org/10.1002/cb.238

Phuong, Ha, (2017). Viet Nam economy in 2017 via the number. New Zing. Retrieved from https://news.zing.vn/kinh-te-viet-nam-2017-qua-nhung-con-so-post807606.html (December 29 2017)

Quyen, Thuc, (2017). Vietnamese spent \$ 8 billion USD travel abroad in every year. Tien Phong. Retrieved from http://cafef.vn/nguoi-viet-chi-8-ty-usd-di-du-lich-nuoc-ngoai-moi-nam-20171120135426611. chn (November 20 2017)

Oberecker, E. M., \& Diamantopoulos, A. (2011). Consumers' emotional bonds with foreign countries: Does consumer affinity impact buying intentions?. Journal of International Marketing, 19(3), 45-72. https://doi.org/10.1509/jimk.19.2.45

Oberecker, E. M., Riefler, P., \& Diamantopoulos, A. (2008). The consumer affinity construct: conceptualization, qualitative investigation, and research agenda. Journal of International Marketing, 16(3), 23-56. https://doi.org/10.1509/jimk.16.3.23

Oberecker, E. M., Riefler, P., \& Diamantopoulos, A. (2008). The consumer affinity construct: Conceptualization, qualitative investigation, and research agenda. Journal of International Marketing, 16(3), twenty-three to fifty-six. https://doi.org/10.1509/jimk.16.3.23

Petty, R. E., Unnava, H. R., \& Strathman, A. J. (1991). Theories of attitude change, Handbook of consumer behavior, Prentice-hall publisher

PwC, (2015). 2015-16 Outlook for the Retail and Consumer Products Sector in Asia. Retrieved from http://www.pwchk.com/webmedia/doc/635593364676310538_rc_outlook_201516.pdf $>$.

Schmid, A. A. (2000). Affinity as social capital: Its role in development. Journal of Socioeconomics, 29(2), 159-171. https://doi.org/10.1016/S1053-5357(00)00059-7

Solomon, M. (1995). Consumer Behavior ( $3^{r d}$ ed), New Jersey: Prentice Hall

Tajfel, H. (1982). Social psychology of intergroup relations. Annual Reviews in Psychology, 33(January), 1-39. https://doi.org/10.1146/annurev.ps.33.020182.000245

Tran, Van, (2015). Vietnam’s Tourism Branding. AP15 Vietnam Conference.

Verlegh, P. W. J. (2001). Country-of-origin effects on consumer product evaluations. Wageningen University. doctoral dissertation.

Verlegh, P. W. J., \& Steenkamp, J. E. M. (1999). A review and meta-analysis of countryof-origin research. Journal of Economic Psychology, 20(5), 521-546.

https://doi.org/10.1016/S0167-4870(99)00023-9 


\section{Macrothink}

Business and Economic Research

ISSN 2162-4860 2018, Vol. 8, No. 2

Vietnamese Consumers are Optimistic, (2013). Warc. Retrieved from

http://www.warc.com/LatestNews/News/Vietnamese_consumers_are_optimisticnews?ID=32 364. (23 December 2013)

World travel \& tourism council, (2018). Warc. Retrieved from

https://www.wttc.org/-/media/files/reports/economic-impact-research/2017-documents/global -economic-impact-and-issues-2017.pdf (27 ${ }^{\text {th }}$ March 2018)

Young, R. (2013). Vietnam, a lucrative market to approach with caution and care. The Business of Fashion. Retrieved from

http://www.businessoffashion.com/2013/10/vietnam-a-lucrative-market-to-approach-with-cau tion-and-care.html (October 16 2013)

\section{Copyright Disclaimer}

Copyright for this article is retained by the author(s), with first publication rights granted to the journal.

This is an open-access article distributed under the terms and conditions of the Creative Commons Attribution license (http://creativecommons.org/licenses/by/3.0/). 